Avalaible online: https://ejournal.iai-tribakti.ac.id/index.php/pgmi

Article doi: https://doi.org/10.33367/jiee.v2i1.1053

\title{
Metode Tikrari Untuk Meningkatkan Hafalan Al-Qur'an Di Mi Al-Huda Sidoarjo
}

\author{
Tikrari Method to Improve Memorization Qur'an \\ at MI Al-Huda Sidoarjo
}

\section{Lailatuz Zuhro ${ }^{1}$ Mufidatus Sholikhah ${ }^{2}$ Valensiana Vortunata Ari Ustoyo ${ }^{3}$ \\ 1,2,3Universitas Islam Negeri Sunan Ampel Surabaya,Indonesia \\ 1'lailatuzzuhro.2@gmail.com; 2mufidatusfida@gmail.com; 3 sianavalen25@gmail.com}

\begin{abstract}
This research is a classroom action research that aims to improve students' memorization ability in fourth grade A class at MI Al Huda Sidoarjo. The material is "Let's Memorize Surah Al-'Adiyat " through Tikrari method. This study used 41 subjects in fourth grade A class at MI Al Huda Sidoarjo on the subject lesson Al-Qur'an Hadith. Researchers used two cycles, each cycle consisting of : (1) Planning, (2) Action, (3) Observation, and (4) Reflection. The researchers collected data using interviews, observations, non-test assessments (performances), and documentation. The results of this study found that : a) The use of the Tikrari method can be used to improve the students' ability in memorizing surah Al-' Adiyat with a positive increase in both student and teacher activities, b) The ability to memorize students increases in the high category with an increase of $43.9 \%$ during precycle to second cycle. The conclusion of this study is the Tikrari method can improve students' memorization ability on the material "Let's Memorize the Surah Al-'Adiyat" in the subject lesson Al-Qur'an Hadith in fourth grade A class at MI Al Huda Sidoarjo.
\end{abstract}

Keywords: Tikrari Method, Memorizing, Surah Al-'Adiyat

\begin{abstract}
Abstrak
Penelitian ini merupakan penelitian tindakan kelas yang bertujuan untuk meningkatkan kemampuan menghafal siswa MI, materi "Mari Menghafal Surah Al-'Adiyat" melalui metode Tikrari. Penelitian ini menggunakan subjek sebanyak 41 siswa kelas IV-A di MI Al Huda Sidoarjo pada mata pelajaran Al-Qur'an Hadits. Peneliti menggunakan dua siklus, setiap siklus terdiri dari : (1) Perencanaan, (2) Tindakan, (3) Observasi, dan (4) Refleksi. Dalam pelaksanaannya, peneliti mengumpulkan data dengan menggunakan wawancara, observasi, penilaian non tes (unjuk kerja atau performances), dan dokumentasi. Hasil dari penelitian ini ditemukan bahwa : a) Penggunaan metode Tikrari dapat digunakan untuk meningkatkan kemampuan menghafal
\end{abstract}


siswa surat Al-'Adiyat dengan adanya peningkatan positif dari aktivitas siswa dan guru, b) Kemampuan menghafal siswa meningkat dalam kategori tinggi dengan peningkatan sebesar 43,9 \% dari pra siklus hingga siklus II. Kesimpulan dari penelitian ini adalah metode Tikrari dapat meningkatkan kemampuan menghafal siswa pada materi "Mari Menghafal Surah Al-'Adiyat" mata pelajaran Al-Qur'an Hadits kelas IV-A di MI Al Huda Sidoarjo.

Kata Kunci: Metode Tikrari, Menghafal, Surah Al-'Adiyat

\section{Pendahuluan}

Mata pelajaran (mapel) AlQur'an hadits adalah bagian dari mapel Pendidikan Agama Islam. Tujuan pembelajaran Al-Qur'an Hadits adalah mendorong siswa untuk mampu membaca dan menulis, membimbing siswa menggemari dan menjadikan kandungannya sebagai pedoman hidup, dan mendorong siswa mengamalkan kandungan ayat Al-Qur'an Hadits dalam kehidupan sehari-hari. ${ }^{1}$ Mapel ini memfokuskan siswa mampu membaca dan menulis Al-Qur'an dan Hadits yang benar, memahami makna secara konteks-tual dan tekstual, mengamalkan kandungannya dalam kehidupan sehari-hari dan menghafal surat-surat pendek pilihan. ${ }^{2}$ Salah satu surat pendek yang wajib untuk dipelajari dan dihafalkan oleh siswa kelas IV-A

\footnotetext{
${ }^{1}$ Keputusan Menteri Agama No 165, "Tentang Kurikulum 2013 Mata Pelajaran Pendidikan Agama Islam dan Bahasa Arab Pada Madrasah" (Jakarta: Kementrian Agama RI, 2014), 40. ${ }^{2}$ Peraturan Menteri Agama Republik Indonesia No. 2, "Tentang Standar Kompetensi Lulusan dan Standar Isi Pendidikan Agama Islam dan Bahasa Arab di Madrasah" (Jakarta: Kementrian Agama RI, 2008), 19.
}

dalam mapel Al-Qur'an Hadits adalah Surat Al-'Adiyat. Surat Al'Adiyat adalah surat ke 100 dalam Al-Qur'an yang terdiri dari 11 ayat dan tergolong dalam surat makkiyah (pendek).

Al-Qur'an merupakan kitab suci yang dijadikan pedoman dan tuntunan hidup manusia. Al-Qur'an merupakan mukjizat dari Allah SWT yang diturunkan kepada Nabi Muhammad SAW dengan perantara malaikat Jibril dan disampaikan kepada kita secara mutawatir serta membacanya terhitung sebagai ibadah. Al-Qur'an memiliki banyak fungsi diantaranya yaitu (1) Al-Huda yang artinya petunjuk bahwa, AlQur'an ini merupakan petunjuk bagi manusia dalam menjalani kehidupan; (2) As-Syifa artinya penyembuh bahwa, Al-Qur'an mampu menyembuhkan kegundahan yang ada dalam hati kita; (3) Al-Furqan artinya pembeda bahwa, Al-Qur'an didalamnya terkandung pembeda antara yang haq dan yang bathil; (4) $A z-Z i k r$ artinya pengingat bahwa, AlQur'an sebagai pemberi peringatan kepada seluruh alam. 
Al-Qur'an merupakan salah satu kitab suci yang dijamin keasliannya sejak diturunkannya kepada Nabi Muhammad SAW sampai sekarang bahkan sampai di hari kemudian. Allah berjanji dalam firmannya yaitu QS. Al-Hijr ayat 9, bahwa Allah menjamin keaslian Al-Qur'an dan memeliharanya. Kita sebagai umat Islam memiliki kewajiban untuk menjaga Al-Qur'an, salah satu caranya yaitu menghafal. Menghafal Al-Qur'an dianjurkan dari usia dini, sehingga bisa mewujudkan rasa cinta terhadap Al-Qur'an dan memeliharanya dengan qalbu. Menghafal Al-Qur'an bukan sesuatu yang sangat sulit bahkan mustahil bagi kita. Allah telah memberi jaminan kepada kita semua tentang kemudahan Al-Qur'an untuk di hafalkan seperti yang terdapat pada firman Allah SWT QS. Al-Qomar ayat 22.

Menghafal Al-Qur'an merupakan suatu perbuatan yang terpuji, mulia dan sangat dianjurkan. Para ulama sepakat bahwa hukum dari menghafal Al-Qur'an yaitu fardhu kifayah artinya orang-orang yang menghafal Al-Qur'an tidak boleh kurang dari jumlah mutawatir. Apabila dalam suatu masyarakat tidak ada seorangpun yang hafal AlQur'an, maka berdosa semuanya. Salah satu tujuan menghafal AlQur'an yaitu membentuk generasi Qur'ani artinya generasi yang melakukan segala perbuatan dan ucapan dengan Al-Qur'an.

Menghafal surat-surat pendek pilihan merupakan salah satu fokus dari pembelajaran Al-Qur'an dan Hadits. Agar siswa mudah dan lebih tertarik untuk menghafalkan surat pendek tersebut maka dibutuhkan sebuah metode dalam sebuah pembelajaran. Metode Tikrari merupakan salah satu metode yang dapat digunakan dalam pembelajaran menghafal Al-Qur'an.

Metode berasal dari kata "metha" berarti melalui atau melewati dan "hodos" jalan atau acara yang harus dilalui untuk mencapai tujuan tertentu. ${ }^{3}$ Sedangkan "Tikrari" berasal dari kata ( نَكَرَارً /

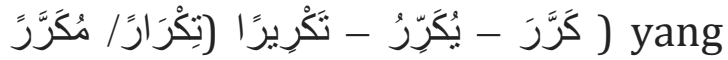
artinya mengulang kembali. 4 Sehingga yang dimaksud dengan Metode Tikrari adalah suatu cara menghafal Al-Qur'an dengan mengulang hafalan baik untuk menambah maupun menjaga hafalan. ${ }^{5}$

Dalam pelaksanaannya, aktivitas dominan dalam metode ini adalah proses mengulang atau mentakrir yaitu mendahulukan hafalan yang baru, kemudian hafalan yang lama. Metode ini disebut juga seperti metode Taqrir atau Tikrar yang memiliki maksud sama. Metode

\footnotetext{
${ }^{3}$ Zuhariri, Metodologi Pendidikan Agama (Solo: Ramadhan, 1993), 66.

${ }^{4}$ Munawir, Kamus Al Munawir (Yogyakarta:

Pustaka Progresif, 1984), 1200.

${ }^{5}$ Zen Muhaimin, Pedoman Pembinaan Tahfidhul Qur'an (Jakarta: PT Maha Grafindo, 2015), 251.
}

el Bidayah: Journal of Islamic Elementary Education Volume 2, Nomor 1, March 2020 
Tikrari juga hampir sama dengan metode pembiasaan yaitu membiasakan seseorang berfikir, bertindak dan berperilaku sesuai tuntutan yang diajarkan.

Dalam metode ini dikenal dengan hafalan baru dan hafalan lama. Hafalan baru adalah hafalan yang akan ditambah atau ayat baru, sedangkan hafalan yang lama adalah hafalan yang sebelumnya telah dihafalkan. Standar yang ideal dari proses mentakrir ini adalah siswa mampu menghafal dengan tidak putus atau terus. Tidak terputusnya hafalan menunjukkan sikap ikhlas dari penghafal. Fokusnya bukanlah kelancaran dari hafalannya. Sehingga takrir harus sesuai dengan kualitas hafalan. Adapun kualitas hafalan tersebut terdiri dari tiga proses a) Pertama, takrir ayat yang belum lancar atau hafalan baru, b) Kedua, takrir ayat yang telah lancar untuk pemeliharaan, dan c) Ketiga, takrir yang sudah lancar kemudian dievaluasi tartil pada ayat-ayat yang sering keliru. ${ }^{6}$

Dengan proses membaca secara rutin dan berulang-ulang akan mengindahkan hafalan serta membantu otak untuk bekerja dari otak kiri ke otak kanan. Otak kanan memiliki daya ingat yang kuat. Untuk masuk ke dalam memori otak kanan, otak membutuhkan waktu

${ }^{6}$ Khoirul Amru Harahap, Metode Tikrari : 30 Hari HafalJuz 'Amma (Jakarta: Qultum Media, 2010). yang cukup lama. Salah satu cara yang efektif yakni dengan proses pengulangan. ${ }^{7}$

Meskipun metode ini membutuhkan waktu yang lama dan konsentrasi yang tinggi, metode ini sangat baik untuk menghafal AlQur'an. Dengan menggunakan metode Tikrari, kualitas dan kuantitas hafalan dapat terjaga dengan baik dan daya ingat siswa menjadi kuat. ${ }^{8}$

\section{Metode}

Penelitian ini menggunakan metode penelitian tindakan kelas. Penelitian tindakan kelas dilaksanakan untuk melakukan perbaikan atau meningkatkan mutu pembelajaran. ${ }^{9}$ Penelitian tindakan kelas termasuk dalam penelitian kuantitatif meskipun data yang dikumpulkan adalah data kualitatif. Peneliti menggunakan model penelitian kelas Kurt Lewin. Model penelitian tindakan kelas Kurt Lewin terdiri atas dua siklus dimana ketika siklus pertama belum berhasil, maka dapat dilanjutkan pada siklus kedua. Gambaran siklus Kurt Lewin terdiri dari empat tahap yaitu : (1) Pe-

\footnotetext{
${ }^{7}$ Mohammad Ikhwanuddin, "Menghafal AlQuran Metode Otak Kanan ala Ustad Rony," http://fai.um-surabaya.ac.id/menghafal-alquran-metode-otak-kanan-ala-ustad-rony/ diakses 20 Januari 2020,.

${ }^{8}$ Amru Harahap, Metode Tikrari : 30 Hari Hafal Juz 'Amma.

${ }^{9}$ Kunandar, Langkah Mudah Penelitian

Tindakan Kelas sebagai Pengembangan Profesi

Guru (Jakarta: Raja Grafindo Persada, 2011), 46.
}

el Bidayah: Journal of Islamic Elementary Education Volume 2, Number 1, March 2020 
rencanaan atau planning, (2)

Pelaksanaan atau acting, (3)

Pengamatan atau observing, (4)

refleksi atau reflecting. ${ }^{10}$

Penelitian ini dilaksanakan di kelas IV-A MI Al-Huda Kecamatan Sidoarjo Kabupaten Sidoarjo. Penelitian ini dilaksanakan pada semester ganjil yaitu bulan November - Desember 2019. Subjek dalam penelitian ini adalah siswa kelas IV-A MI tahun pelajaran 2018/2019. Jumlah siswa di kelas IV-A MI Al Huda Sidoarjo yaitu 41 siswa terdiri dari 25 siswa laki-laki dan 16 siswa perempuan. Kompetensi dasar yang menjadi acuan penelitian dalam mata pelajaran $\mathrm{Al}$ Qur'an Hadits ini adalah 4.2 "Menghafalkan QS. Al-'Adiyat (100) secara benar dan fasih."

Variabel yang diteliti dalam PTK ini adalah meningkatkan kemampuan menghafal siswa dengan metode Tikrari pada mata pelajaran Al-Qur'an Hadits "Mari Menghafal Surah Al-'Adiyat." Disamping itu, masih ada tiga variabel lain yaitu : (1) Variabel input: Siswa kelas IV-A MI Al Huda Sidoarjo, (2) Variabel proses: Penerapan metode Tikrari, (3) Variabel output: Peningkatan kemampuan menghafal surat Al-'Adiyat. Teknik pengumpulan data yang digunakan oleh peneliti adalah wawancara, observasi, penilaian non tes / unjuk

10 Fauti Subhan, Penelitian Tindakan Kelas

(Sidoarjo: Qisthos Digital Press, 2013), 91.

el Bidayah: Journal of Islamic Elementary Education

Volume 2, Nomor 1, March 2020 kerja (performance), dan dokumentasi. Instrumen pengumpulan data yang digunakan meliputi lembar pengamatan aktivitas guru, siswa, dan unjuk kerja (performance) siswa.

\section{Temuan dan Pembahasan}

\section{Mata Pelajaran Al-Qur'an dan Hadits}

Mapel Pendidikan Agama Islam memiliki porsi lebih banyak daripada pengetahuan umum. Salah satu mapel dari Pendidikan Agama Islam tersebut adalah Al-Qur'an Hadits. Kajian dalam Al-qur'an Hadits bersumber pada akidahakhlak, ibadah dan muamalah. ${ }^{11}$ Sehingga Mapel tersebut menekankan kemampuan membaca dan menulis, memahami makna secara kontekstual dan tekstual, serta pengamalan kandungan Al-Qur'an dan Hadits dalam kehidupan seharihari. Selain itu siswa juga dituntut mampu menghafal beberapa surat pendek pilihan dan hadits-hadits tentang akhlak terpuji untuk diamalkan dalam kehidupan seharihari dengan keteladanan dan pembiasaan. ${ }^{12}$

Ruang lingkup mapel AlQur'an Hadits di MI meliputi; a) Kemampuan dasar membaca dan menulis Al-Qur'an Hadits sesuai

\footnotetext{
${ }^{11}$ Keputusan Menteri Agama No 165, “Tentang Kurikulum 2013 Mata Pelajaran Pendidikan Agama Islam dan Bahasa Arab Pada Madrasah," 39.

${ }^{12}$ Keputusan Menteri Agama No 165, 38. 
dengan kaidah ilmu tajwid, b) Hafalan surat-surat pendek dalam Al-Qur'an dan pemahaman sederhana tentang arti dan makna kandungannya, serta pengamalannya melalui keteladanan dan pembiasaan melalui kehidupan sehari-hari, c) Pemahaman dan pengamalan melalui keteladanan dan pembiasaan mengenai haditshadits yang berkaitan dengan keutamaan membaca Al-Qur'an, kebersihan, niat, menghormati orang tua, persaudaraan, silaturrahim, takwa, keutamaan memberi, menyayangi anak yatim, sholat berjama'ah, ciri-ciri orang munafik, dan amal salih. ${ }^{13}$ Hal ini bertujuan agar a) Siswa memiliki kemampuan dasar dalam membaca, menulis, membiasakan dan menggemari membaca Al-Qur'an dan Hadits, b) Mendorong dan membimbing perilaku siswa dengan berpedoman pada isi kandungan ayat Al-Qur'an dan Hadits, c) Menanamkan pengertian, pemahaman, peghayatan dan pengalaman kandungan ayat-ayat $\mathrm{Al}$ Qur'an dan Hadits dalam perilaku siswa sehari-hari melalui keteladanan dan pembiasaan, d) Memberikan bekal pengetahuan untuk mengikuti pendidikan pada jenjang yang setingkat lebih tinggi. ${ }^{14}$

\footnotetext{
13 Peraturan Menteri Agama Republik Indonesia No. 2, "Tentang Standar Kompetensi Lulusan dan Standar Isi Pendidikan Agama Islam dan Bahasa Arab di Madrasah," 23.

${ }^{14}$ Keputusan Menteri Agama No 165, "Tentang Kurikulum 2013 Mata Pelajaran Pendidikan 18
}

Salah satu surat pendek yang wajib di hafalkan pada kelas IV-A di MI Al Huda Sidoarjo adalah surat Al'Adiyat. Surat tersebut memiliki karakteristik yang mana ayat satu dengan yang lainnya memiliki kemiripan. Dari hasil studi pendahuluan (pre-liminary research), ditemukan siswa mengalami permasalahan yakni kesulitan dalam memahami materi surat ini. Hal inilah yang menyebabkan rendahnya hasil belajar siswa pada materi "Mari Mengahafal Surah Al-'Adiyat". Sehingga surat Al-'Adiyat menjadi fokus pada penelitian ini.

\section{Surat Al-'Adiyat}

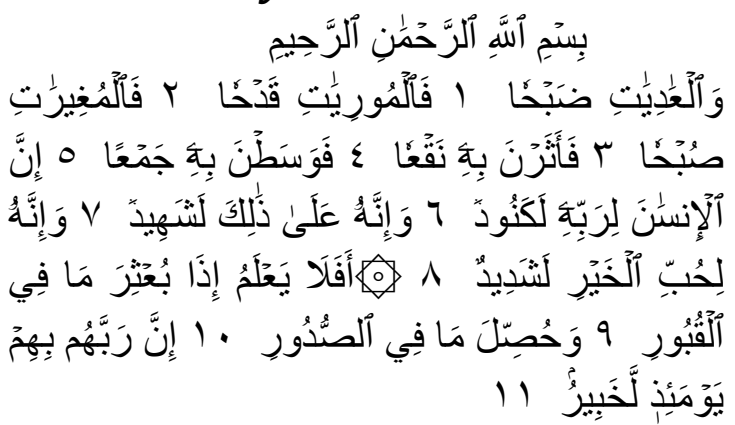

Artinya:

1. Dengan nama Allah, Yang Maha Pengasih, Maha Penyayang. Demi kuda perang yang berlari kencang dengan terengah-engah,

2. Dan kuda yang mencetuskan api dengan pukulan (kuku kakinya),

3. Dan kuda yang menyerang dengan tiba-tiba di waktu pagi,

4. Maka ia menerbangkan debu,

5. Dan menyerbu ke tengah-tengah kumpulan musuh,

Agama Islam dan Bahasa Arab Pada Madrasah," 40. Volume 2, Number 1, March 2020 
6. Sesungguhnya manusia itu sangat ingkar, tidak berterima kasih kepada Tuhannya,

7. Dan sesungguhnya manusia itu menyaksikan keingkarannya,

8. Dan sesungguhnya dia sangat bakhil karena cintanya kepada harta.

9. Maka apakah dia tidak mengetahui apabila dibangkitkan apa yang ada di dalam kubur,

10. Dan dilahirkan apa yang ada di dalam dada,

11.Sesungguhnya Tuhan mereka pada hari itu Maha Mengetahui keadaan mereka. ${ }^{15}$

\section{Menghafal Al-Qur'an}

Secara etimologi, kata menghafal berasal dari kata يفظ - yang berarti menjaga, memelihara, dan melindungi. Secara terminologi, kata menghafal memiliki arti yaitu sebuah tindakan yang dilakukan untuk meresapkan ilmu kedalam pikiran agar selalu diingat. Menghafal yang dimaksud oleh peneliti disini adalah menghafal Al-Qur'an.16 Menghafal Al-Qur'an adalah sikap dan aktivitas yang mulia, dengan mengaplikasikan serta menjaga keaslian Al-Qur'an.

${ }^{15}$ Al-Qur'an Hadis: Buku siswa Kementrian Agama Republik Indonesia (Jakarta: Kementrian Agama Republik Indonesia, 2014).

16 Tim Penyusun Kamus Pusat Pembinaan dan Pengembangan Bahasa, Kamus Besar Bahasa Indoenesia, Departemen Pendidikan dan Kebudayaan, 4 ed. (Jakarta: Balai Pustaka, 1993), 57.

el Bidayah: Journal of Islamic Elementary Education

Volume 2, Nomor 1, March 2020
Tujuan menghafal Al-Qur'an yaitu agar kita semua mampu membaca dan memahami isi dalam Al-Qur'an dengan benar. ${ }^{17}$

Selain tujuan, ada beberapa manfaat menghafal Al-Qur'an yaitu : (1) Agar memiliki ingatan yang tajam dan bersi, (2) Agar memiliki kosakata bahasa arab yang lebih banyak, (3) Agar bisa mengeluarkan dalil-dalil dari ayat-ayat Al-Qur'an dengan cepat. Faktor yang mempengaruhi kemampuan menghafal Al-Qur'an yaitu : (1) Kesiapan fisik, (2)Kesiapan psikologis, (3) Kesiapan IQ. Faktor-faktor tersebut sangat penting sebagai tolak ukur keberhasilan menghafal Al-Qur'an. Dalam penilaian menghafal AlQur'an ada beberapa indikator yang perlu diperhatikan yaitu : (1) Kefasihan, (2) Ketepatan Tajwid, (3) Kelancaran menghafal bacaan. ${ }^{18}$

Tikrari diambil dari kata ( تَكْرَرَارَ

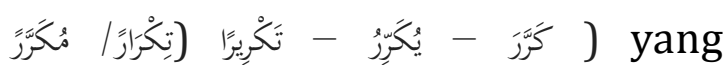
memiliki arti mengulang kembali. ${ }^{19}$ Metode Tikrari yaitu menghafal AlQur'an dengan mengulang hafalan baik menambah hafalan atau tidak menambah yang sudah diperdengarkan kepada instruktur. Metode ini sangat dominan dan

\footnotetext{
17 Abdul Aziz Abdul Rauf, Kiat Sukses Menjadi Hafizh Qur'an Da'iya (Bandung: Syaamil Cipta Media, 2004), 52.

${ }^{18}$ Abdul Muhsin Al-Qosim, Cara Praktis Menghafal Al-Qur'an Makrab (Madinah AlMunawwarah: Dakwah dan Bimbingan Jaliyat Rabwah, 2007), 132.

19 Munawir, Kamus Al Munawir, 1200.
} 
dapat digunakan secara praktis. Menurut Khoirul Amru Harahap, langkah-langkah dalam menghafal Al-Qur'an menggunakan metode Tikrari yaitu sebagai berikut:

1. Ustadz membacakan ayat pertama, murid mendengarkan dan menirukan bacaan Ustadz. Jika pelafalan sudah benar, maka murid menghafalkan ayat pertama berdasarkan bacaan ustadz.

2. Setelah murid hafal ayat pertama, Ustadz menguji hafalan murid terhadap ayat pertama, baik secara klasikal maupun secara berkelompok dan idividual.

3. Ustadz membacakan ayat kedua, murid mendengarkan dan menirukan bacaan Ustadz. Jika pelafalan sudah baik dan benar, maka murid menghafalkan ayat kedua berdasarkan bacaan Ustadz.

4. Setelah murid hafal ayat kedua, Ustadz menguji hafalan murid terhadap ayat kedua, baik secara klasikal maupun berkelompok dan individual.

5. Ustadz menyuruh murid untuk mengulang hafalan terhadap ayat pertama dan kedua, baik secara klasikal maupun berkelompok dan individual.

6. Ustadz membacakan ayat ketiga, murid mendengarkan dan menirukan bacaan Ustadz.

7. Ustadz menyuruh murid untuk mengulang hafalan mulai dari ayat pertama sampai ketiga, baik secara klasikal maupun berkelompok dan individual.

8. Jika murid telah hafal materi hafalan dalam satu majmu'ah, boleh melanjutkan ke materi hafalan majmu'ah berikutnya. ${ }^{20}$

Bedasarkan hasil penelitian di lapangan, langkah-langkah yang telah dilaksanakan oleh peneliti dalam melakukan penerapan metode Tikrari di kelas IV-A MI Al Huda Sidoarjo adalah sebagai berikut :

1) Guru bersama siswa membaca surat Al-'Adiyat secara bersamasama sambil melihat media lembar Kartu Pelangi Al-'Adiyat di papan tulis.

2) Guru membagikan LK Hafalan Surat Al-'Adiyat kepada siswa.

3) Guru membaca ayat pertama dari surat Al-'Adiyat dengan suara lantang, sambil memberi tanda pada kartu pelangi $\mathrm{Al}$ 'Adiyat peserta didik mendengarkan sekaligus menyimak dengan seksama.

4) Peserta didik menirukan bacaan ayat pertama yang dibacakan oleh guru secara bersama-sama dengan bin-nadhor sebanyak lima kali, sambil mencentang LK Hafalan Surat Al-'Adiyat.
20 Khoirul Amru Harahap, Metode Tikrari 30 Hari Hafal Juz 'Amma Seri B (Jakarta Selatan: PT Agromedia Pustaka, t.t.), 8.

el Bidayah: Journal of Islamic Elementary Education Volume 2, Number 1, March 2020 
5) Setelah satu ayat tersebut ada dampaknya dan hafal dengan lancar.

6) Setelah materi satu ayat ini dikuasai hafalannya dengan hafalan yang betul-betul lancar oleh peserta didik, maka diteruskan dengan menambah materi ayat-ayat baru dengan memperhatikan guru membaca ayat selanjutnya. Kemudian peserta didik membaca secara bin-nadhor terlebih dahulu dan mengulang-ulang sebagaimana ayat pertama.

7) Setelah mendapatkan hafalan dua ayat dengan baik dan lancar. Sudah tidak mendapatkan kesalahan lagi, maka hafalan tersebut diulang-ulang mulai dari ayat pertama dirangkai dengan ayat kedua sebanyak sepuluh kali, kemudian lanjut ke ayat-ayat berikutnya sampai batas waktu yang disediakan habis dan pada materi surat yang telah ditargetkan.

8) Setelah materi surat Al-'Adiyat = yang telah ditentukan menjadi hafal dengan baik dan lancar, lalu hafalan diperdengarkan/ disetorkan dihadapan guru.

\section{Penerapan Metode Tikrari di MI AI Huda Sidoarjo}

Pada penerapan metode Tikrari ini, peneliti melakukan penelitian tindakan kelas selama dua siklus pembelajaran. Penggunaan metode ini dapat membantu meningkatkan kemampuan siswa pada materi "Mari Menghafal Surah Al-'Adiyat". Hal ini dibuktikan berdasarkan hasil observasi, siswa menjadi tanggap, aktif dan daya ingatan siswa juga meningkat serta kuat. Pada saat pembelajaran materi "Mari Menghafal Surah Al-'Adiyat", awal-nya siswa mengalami kesulitan. Dikarenakan banyak ayat mutasyabihat pada surat Al-'Adiyat. Bedasarkan hasil wawancara dengan beberapa siswa, siswa merasa lebih mudah dalam menghafal ketika memakai metode ini, dan metode ini begitu menyenangkan dan efektif. Begitupun dengan wawancara yang dilakukan kepada Guru Al-Qur'an Hadits. Beliau merasa terbantu dengan adanya metode ini. Metode ini dirasa guru cukup inovatif dan menarik.

Peningkatan nilai akhir aktivitas guru dan siswa pada siklus I dan siklus II yang disajikan dalam disajikan tabel 1 sebagai berikut:

\section{Tabel 1}

\section{Hasil Nilai Aktivitas Guru dan Siswa}

\begin{tabular}{|l|l|l|l|}
\hline K & S I & S II & Pe \\
\hline Aktivitas & 83,7 & 97,5 & 13,7 \\
Guru & 5 & & $5 \%$ \\
\hline Aktivitas & 82,5 & 98,7 & 16,2 \\
Siswa & & 5 & $5 \%$ \\
\hline
\end{tabular}

Ket:

$\mathrm{K}$ : Keterangan

S I: Siklus I 
SII: Siklus II

Pe: Peningkatan dari siklus I ke

Siklus II

\section{Peningkatan Kemampuan Meng- hafal Siswa Kelas IV-A}

Berdasarkan penilaian performance yang telah dilakukan, diperoleh data bahwa pada pra siklus kemampuan menghafal siswa mendapat nilai rata-rata 68,26 termasuk kategori sangat kurang dan persentase ketuntasan belajar sebesar 48,78\% dengan mendapatkan kategori kurang. Pada siklus I kemampuan menghafal siswa mendapat nilai rata-rata kelas 79,08 termasuk kategori cukup dan persentase ketuntasan belajar sebesar $70,73 \%$ dengan mendapatkan kategori cukup, siswa yang memenuhi KKM sebanyak 29 dari 39 siswa.

Pada siklus II dengan materi yang sama, nilai rata-rata kelas sebanyak 90,65 yang dapat dikategorikan baik, untuk persentase ketuntasan belajar se-banyak 92,68\% dapat dikategorikan baik, untuk siswa yang berhasil memenuhi KKM sebanyak 38 dari 41 siswa.

Data peningkatan (1) nilai ratarata siswa dan jumlah siswa yang tuntas dan (2) pesentase tingkat ketuntasan siswa dapat dilihat dalam diagram 1 dan 2 sebagai berikut :
Diagram 1

\section{Hasil Nilai Rata-rata dan Jumlah siswa yang Tuntas}

Hasil Nilai Rata-rata \& Jumlah ketuntasan

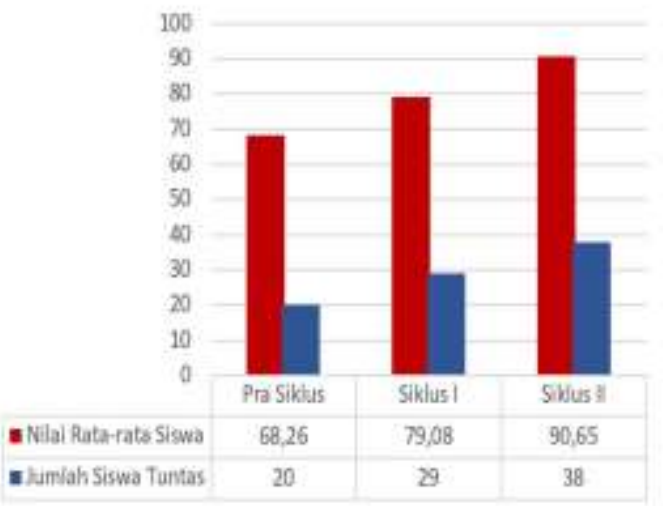

Diagram 2

Persentase Tingkat Ketuntasan Siswa

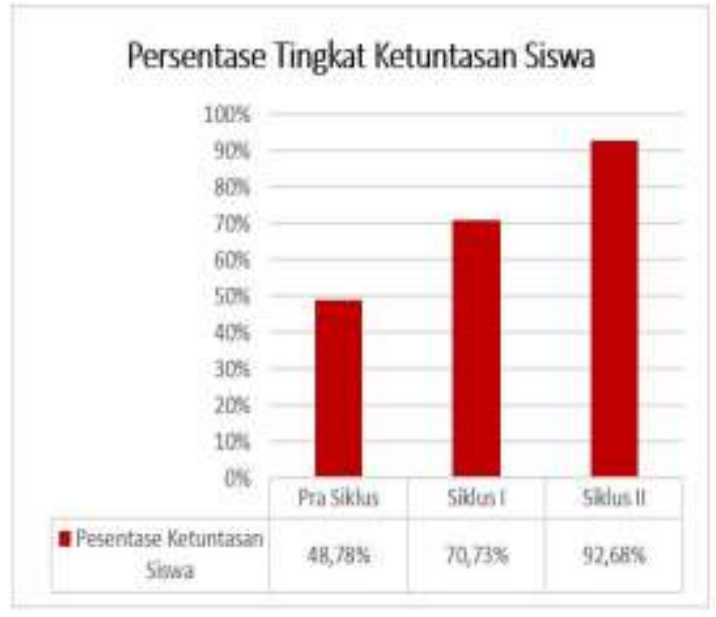

Metode Tikrari berhasil diterapkan di kelas IV-A. Hal ini dibuktikan terdapat peningkatan persentase aktivitas dari guru dan siswa dari siklus I hingga siklus II. Metode Tikrari memberikan peningkatan positif dalam proses pembelajaran menghafal pada mapel Al-Qur'an Hadits. 
Peningkatan kemampuan menghafal siswa dari pra siklus hingga ke siklus II ditemukan sebesar 43,9\% termasuk dalam kategori tinggi. Pembelajaran menghafal Al-Qur'an melalui metode Tikrari ini mampu membantu dan meningkatkan kemampuan menghafal siswa.

Secara lebih jelas, berikut disajikan tabel 2 ringkasan hasil penelitian dari tahap pra siklus hingga siklus II.

\section{Tabel 2}

\section{Ringkasan Hasil Penelitian}

\begin{tabular}{|c|c|c|c|c|}
\hline $\mathbf{K}$ & $\mathbf{P}$ & S I & S II & Pe \\
\hline Akvt. Guru & 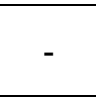 & $\begin{array}{l}83 \\
75 \\
\end{array}$ & $\begin{array}{c}97 \\
5 \\
\end{array}$ & $\begin{array}{c}13,7 \\
5 \% \\
\end{array}$ \\
\hline Akt. 5 & - & 82,5 & $\begin{array}{l}98 \\
75 \\
\end{array}$ & $\begin{array}{c}16,2 \\
5 \% \\
\end{array}$ \\
\hline $\begin{array}{l}\text { Rata-rata } \\
\text { kelas }\end{array}$ & $\begin{array}{c}68,2 \\
6\end{array}$ & $\begin{array}{l}79 \\
08\end{array}$ & $\begin{array}{l}90 \\
65\end{array}$ & $\begin{array}{c}11,5 \\
7 \%\end{array}$ \\
\hline $\begin{array}{c}\text { Tingkat } \\
\text { ketuntasan } \\
(\%)\end{array}$ & $\begin{array}{l}48,7 \\
8 \%\end{array}$ & $\begin{array}{c}70,7 \\
3 \%\end{array}$ & $\begin{array}{l}92,6 \\
8 \%\end{array}$ & $\begin{array}{c}21,9 \\
5 \%\end{array}$ \\
\hline $\begin{array}{l}\text { Jumlah } \\
\text { siswa yang } \\
\text { tuntas }\end{array}$ & $\begin{array}{c}20 \\
\text { dari } \\
39 \\
\text { sisw } \\
\text { a } \\
\end{array}$ & $\begin{array}{c}29 \\
\text { dari } \\
39 \\
\text { sis } \\
\text { wa }\end{array}$ & $\begin{array}{c}38 \\
\text { dari } \\
41 \\
\text { sis } \\
\text { wa } \\
\end{array}$ & \\
\hline
\end{tabular}

Ket:

$\mathrm{K}:$ Keterangan

$\mathrm{P}$ : Pra Siklus

S I: Siklus I

SII: Siklus II

Pe: Peningkatan dari siklus I ke Siklus II

Berdasarkan tabel ringkasan hasil penelitian diatas, dapat disimpulkan bahwa hasil penelitian mengalami peningkatan dalam lima aspek yakni : (1) Aspek aktivitas guru siklus I dan siklus II meningkat menjadi 13,75\%. (2) Aspek aktivitas peserta didik siklus I dan siklus II meningkat menjadi $16,25 \%$. Aspek rata-rata kelas dari pra siklus ke siklus I meningkat sebesar 10,82\%. Lalu dari siklus I ke siklus II meningkat sebesar $11,57 \%$. Aspek ketuntasan belajar dari pra siklus ke siklus I meningkat menjadi 21,95\%. Kemudian dari siklus I ke siklus II meningkat dengan persentase sebesar 21,95\%. Aspek jumlah siswa yang tuntas, pra siklus 20 dari 39 siswa, kemudian siklus I meningkat sebanyak 29 dari 39 siswa serta siklus II menjadi 38 dari 41 siswa.

\section{Kesimpulan}

Berdasarkan hasil penelitian dan pembahasan yang diperoleh tentang "Metode Tikrari Untuk Meningkatkan Hafalan Al-Qur'an di MI Al-Huda Sidoarjo" dapat disimpulkan sebagai berikut:

1. Penerapan metode tikrari untuk meningkatkan hafalan Al-Qur'an di kelas IV-A MI Al Huda Sidoarjo sudah terlaksana dengan efektif dan menyenangkan.

2. Hasil nilai aktivitas guru dan siswa pada siklus I yaitu 83,75 dan 82,5 . Hasil nilai aktivitas guru dan siswa pada siklus II yaitu 97,5 dan 98,75. Hasil nilai aktivitas guru dan siswa pada siklus I ke siklus II meningkat yaitu 13,75 dan 16,25 . 
3. Hasil rata-rata siswa kelas IV-A MI Al Huda Sidoarjo pada pra siklus yaitu 68,26 termasuk kategori sangat kurang. Pada siklus I memperoleh hasil 79,08 termasuk kategori cukup dan meningkat pada siklus II yaitu 90,65 termasuk dalam kategori baik. Peningkatan hafalan siswa dari pra siklus ke siklus II termasuk dalam kategori tinggi yaitu sebesar 43,9\%.

\section{Daftar Pustaka}

Al-Qosim, Abdul Muhsin. Cara Praktis Menghafal Al-Qur'an Makrab. Madinah Al-Munawwarah: Dakwah dan Bimbingan Jaliyat Rabwah, 2007.

Al-Qur'an Hadis: Buku siswa Kementrian Agama Republik Indonesia. Jakarta: Kementrian Agama Republik Indonesia, 2014.

Amru Harahap, Khoirul. Metode Tikrari: 30 Hari HafalJuz 'Amma. Jakarta: Qultum Media, 2010.

Harahap, Khoirul Amru. Metode Tikrari 30 Hari Hafal Juz 'Amma Seri B. Jakarta Selatan: PT Agromedia Pustaka, t.t.

Ikhwanuddin, Mohammad. "Menghafal Al-Quran Metode Otak Kanan ala Ustad Rony." Diakses 20 Januari 2020. http://fai.umsurabaya.ac.id/menghafal-al- quran-metode-otak-kananala-ustad-rony/.

Keputusan Menteri Agama No 165. “Tentang Kurikulum 2013 Mata Pelajaran Pendidikan Agama Islam dan Bahasa Arab Pada Madrasah." Jakarta: Kementrian Agama RI, 2014.

Kunandar. Langkah Mudah Penelitian Tindakan Kelas sebagai Pengembangan Profesi Guru. Jakarta: Raja Grafindo Persada, 2011.

Muhaimin, Zen. Pedoman Pembinaan Tahfidhul Qur'an. Jakarta: PT Maha Grafindo, 2015.

Munawir. Kamus Al Munawir. Yogyakarta: Pustaka Progresif, 1984.

Peraturan Menteri Agama Republik Indonesia No. 2. "Tentang Standar Kompetensi Lulusan dan Standar Isi Pendidikan Agama Islam dan Bahasa Arab di Madrasah." Jakarta: Kementrian Agama RI, 2008.

Rauf, Abdul Aziz Abdul. Kiat Sukses Menjadi Hafizh Qur'an Da'iya. Bandung: Syaamil Cipta Media, 2004.

Subhan, Fauti. Penelitian Tindakan Kelas. Sidoarjo: Qisthos Digital Press, 2013.

Tim Penyusun Kamus Pusat Pembinaan dan Pengembangan Bahasa. Kamus Besar Bahasa Indoenesia, Departemen Pendidikan dan Kebudayaan,. 4 
ed. Jakarta: Balai Pustaka, 1993.

Zuhariri. Metodologi Pendidikan

Agama. Solo: Ramadhan, 1993. 
Metode Tikrari Untuk Meningkatkan Hafalan...

Oleh: Lailatuz Zuhro, Mufidatus Sholikghah, Valensiana Vortunata Ari Ustoyo 